\title{
Relationship between Competitive Strategies and Growth of Private Universities in Nairobi County, Kenya
}

\author{
Nyambura Mary ${ }^{1}$, Muema Wilson2, Bichange Methuselah ${ }^{2}$ \\ ${ }^{1,2,3}$ Kenya Methodist University
}

\begin{abstract}
The current operational set-up in Kenya's universities is a turbulent one since it is in highly competitive market condition. To ensure survival and sustainability in the market place the private universities require adopting a competitive strategy. The purpose of this study was to establish the relationship between competitive strategies and the growth of private universities in Kenya. This research problem was studied using a descriptive survey design. The target population comprised 242 marketing and management staff working with private universities in Nairobi County, Kenya. A sample of 71 respondents was obtained from the study population using stratified random sampling method. A structured questionnaire was used to collect primary data. Data analysis were facilitated by the use of Statistical Package for Social Sciences computer software. Both descriptive and inferential statistics were used in the analysis. The study results were presented in form of tables. The study revealed that the relationship between differentiation strategies and growth of private universities was positive, strong and significant. The study also found that private universities have recorded growth in various facets including student enrolment, workforce, programmes, courses, and satellite campuses. The study concluded that differentiation strategies were imperative in enhancing growth of private universities. The study further inferred that the more focused private universities were in reference to the strategies they employed, the more they were likely to witness organizational growth. It is recommended that it is imperative for private universities to offer only those courses and programmes which they have the requisite capacity in order to avoid straining its resources. The study also recommended that that the growth of private universities should also be balanced and also be in line with the guidelines of the Commission of University Education.
\end{abstract}

Keywords: Competitive strategies, differentiation strategies, Nairobi County, organizational growth, private universities

\section{Introduction}

Competitive strategies consist of all those moves and approaches that a firm has and is taking to attract buyers, withstand competitive pressure and improve its market position. Competitive strategies are employed by firms within a particular industry. The strategies adopted are expected to relate to performance of the company. It is stated that long term strategy should derive from a firms attempt to seek and sustain a competitive advantage based on one of the three generic strategies [1]. These are cost leadership, differentiation and focus strategies. Competitive strategies encompass the moves that are possessed by given firm and which it capitalizes on to attract customers and also to withstand competitive pressure, thus improving its market position [2].

It is asserted that there is increased expectations in higher education globally majorly through provision of excellent and quality education and research. The foregoing justifies the emphasis on competitive strategies. In this respect, therefore, the need for strategic management in public institutions, more specifically universities, varies to a significant extent when compared to other organizations [3]. The foregoing implies that the competitive strategies that are or should be adopted by institutions of higher education are supposed to be unique to them.

It is postulated that, there have been unprecedented changes that have been witnessed in institutions of higher education in Sub-Saharan Africa [4]. These important changes include increased enrolment, declining funding for higher education from the government, decentralization of responsibility to the institutional level, increased government regulations to enhance quality, globalization of higher education, introduction of advanced technologies including information and communications technology (ICT), and also international competition for funds, faculty and students. It is reported that, in Sub-Saharan Africa, the enrolment of students has increased more than three folds from 2.7 million in 1991 to 9.3 million in 2006. The report projected a rise of enrolment of university students to the region of 18 million to 20 million in 2015 across Africa.

It is indicated that private universities in Kenya have experienced exponential growth in the recent past. However, the rapid growth of these academic institutions has not been accompanied by enhanced of quality standards. As at 2012, there were 30 private universities in Kenya chartered or with interim charter. Nairobi County and its environs had 11 private universities. About $20 \%$ of university students are enrolled in private universities [5]. The growth of private universities has obliged public universities to join the fray of expanding their institutions. Indeed, the self-sponsored degree programmes offered by public universities is modelled around programmes offered by private universities. This change of strategy among public universities has stiffened further the competition that private universities have been facing.

\section{Statement of the Problem}

Competitive strategies employed by firms in their operations vary widely depending on the operating environment. The current operational set up in Kenya's education sector is a dynamic one and highly competitive with the emergence of 


\section{International Journal of Science and Research (IJSR) \\ ISSN (Online): 2319-7064}

Index Copernicus Value (2015): 78.96 | Impact Factor (2015): 6.391

many private universities. The privatization of university education and liberation of student selection since the formation of Commission of University Education in 2012 changed the environment in which the private universities operated. This has affected the performance and growth of private universities negatively due to competition and establishment of many such universities. The hitherto expansion of public universities through setting up of satellite campuses has compounded the competition previously faced by private universities.

Given that private universities are ideally profit-driven; their survival in the higher education sector is paramount. This is only possible if they have the capacity to stifle the prevailing heightened competition in the sector. Unlike the public universities which have for long been receiving financial support from the State, private universities primarily rely on tuition fees as their source of revenue. Resultantly, they charge significantly higher fees that public universities; a factor that has made them less attractive. Private universities have been facing serious financial constraints stemming from decreased funding sources and also an increase in cost of operations. Thus, it is quite impossible for these institutions to be cost leaders in the higher education sector.

Though private universities have differentiated in by employing technologies [5], it remains largely unclear the extent to which differentiation strategy affects their growth. Against this backdrop, therefore, it was imperative to evaluate the influence of competitive strategies, particularly differentiation strategies on growth of private universities in Kenya

\section{Objectives of the Study}

\subsection{General Objective}

To establish the relationship between competitive strategies and growth of private universities in Nairobi County, Kenya.

\subsection{Specific Objective}

To assess the relationship between differentiation strategy and growth of private universities in Nairobi County.

\section{Research Hypothesis}

$\mathbf{H}_{\mathbf{0}}$ : There is no significant relationship between differentiation strategies and growth of private universities in Nairobi County.

\section{Conceptual Framework}

A conceptual framework refers to a diagrammatic representation of study variables and how they are hypothesized to interact. The conceptual framework for this study is shown in Figure 1.

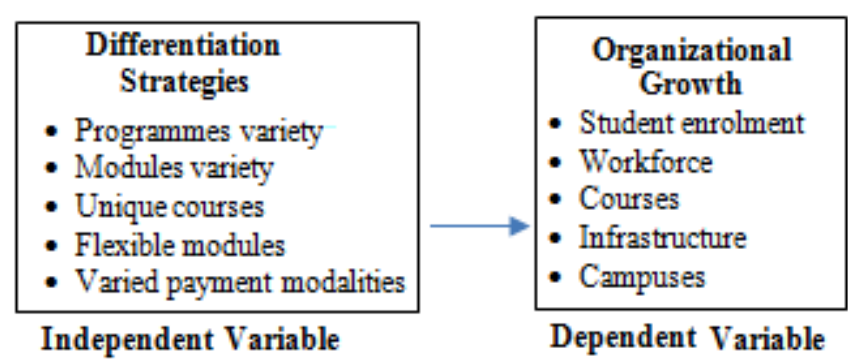

Figure 1: Conceptual Framework

As indicated in Figure 1, there are two set of study variables which are independent and dependent variables. Independent variable constituted differentiation strategies, while the growth of private universities constituted the dependent variable. As shown in the framework, it was hypothesized that differentiation strategies influenced growth of private universities. This proposition guided the study.

\section{Literature Review}

Theories and empirical studies in respect of competitive strategies and organizational growth were reviewed.

\subsection{Theoretical Framework}

The study was guided by the strategic balancing theory.

\subsubsection{Theory of Strategic Balancing}

Strategic balancing is founded on the premise that the strategy of an organization is partly comparable to the strategy of an individual. Certainly, the performance of organizations is affected by the actors ${ }^{\text {ee }}$ behaviour, such as

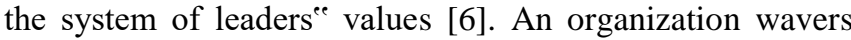
between many antagonistic poles that signify cooperation and competition. This allows for existence of various configurations of alliances that disappear only if the alliance swings in the direction of a mainstream of poles of confrontation. Strategic balancing is comprised of three models which include: relational, symbiotic and deployment models. Competition attests to be part of the relational model and the model of deployment. It can be liable to undulation between the two aggressive strategies, one being primarily cooperative as depicted by the relational model and the other being predominantly competing as exemplified by the model of deployment. The organization can then take turns in adopting the two strategies so as to keep their relationship balanced [7]. There are three types of competitive relationships: competition-dominated, cooperation- dominated, and equal relationships [7].The latter is also comparable to the fluctuation between the relational model and the model of deployment [8]. Competitive strategies, should concentrate on the management-needs recognition process. A number of Universities have achieved this. TheKey Intelligence Topics (KIT) process was used to identify and prioritize the major intelligence needs of senior management and the organization itself [9]. This made sure that intelligence operations were successful and suitable intelligence was produced. Their approach is valuable since it allows corporate intelligence staff to recognize strategic issues and as a result senior management can guarantee that action is taken regarding the results given. The additional advantages 


\section{International Journal of Science and Research (IJSR) \\ ISSN (Online): 2319-7064}

Index Copernicus Value (2015): 78.96 | Impact Factor (2015): 6.391

are that an early warning system can be created and this will allow possible threats to the organization and major players in the industry are identified and monitored.

\subsection{Empirical Review}

This section puts into perspective a review of empirical studies that have hitherto been carried out in respect of differentiation strategies and organizational growth primarily in institutions of higher education particularly private universities.

\subsubsection{Differentiation Strategies and Organizational Growth}

A number of studies have been done on competitive strategies but under different contexts in Kenya. An analysis of the competitive strategies in the petroleum industry and found that service stations use differentiation as a method of obtaining competitive advantage over other service stations [10]. Another study examined the competitive strategies employed by private universities in Kenya [5]. The study focused on private universities in Nairobi. The study analyzed how private universities have used technologies and innovations as competitive strategies. The study further examined how differentiation strategies have enabled these institutions of higher learning to have a competitive edge over their rivals in the sector. The findings of the study indicated that private universities have actually adopted technology and also differentiated their products and services. These institutions were further revealed to have leading products in the education sector which have granted them a competitive advantage over other related institutions. In the same vein, an investigation of challenges facing PAC University in Nairobi as a case study of other Christian universities operating in Kenya was carried out [11]. The sampled employees working with the university and the student leaders were of the opinion that differentiation was a feasible strategy in addressing problems facing the institution. This was supported by majority of the sampled respondents strongly agreeing (64.3\%) that the differentiation strategy could have effectively been employed to address the challenges facing the PAC University in Nairobi.

\subsubsection{Organizational Growth}

In the People's Republic of China, an empirical study on barriers to entrepreneurial growth was carried out [12]. The study empirically analyzed university spin-offs (USOs) in China. The study which was a nationwide survey was conducted across 69 national university science parks in the country. The primary objective of the study was to examine the variable growth barriers to Chinese USOs. In particular, the study sough to establish the significance of the growth barriers and what both the government and the universities were supposed to do in order to get rid of the mentioned barriers. The study found that managerial concerns, lack of infrastructure and issues touching on corporate governance were the leading barriers that averted the growth of USOs in China.

A local study examined the role of institutional managers in quality assurance [13]. The study looked into the reflections on university education in Kenya. The growth of universities is contingent to the input of the management. In addition, universities and their managers are accountable to the stakeholders. The study indicated that, for the appointed managers to justify their existence in universities and their continued hold on the management positions, they are supposed to guarantee the stakeholders the institutions they manage and lead are able to record growth in terms of quality teaching, research and community service. In terms of performance, the study observed that private universities were better than public universities particularly in respect to management of quality education. There were other factors that were found to inhibit performance and growth of universities, both public and private. These factors included lack of sufficient teaching and learning resources and a leadership that failed to satisfactorily involve stakeholders in decision making.

A local study empirically assessed the determinants of academic employee retention in public universities in Kenya [14]. Retention of employees was an indicator of organizational growth. The study acknowledged that retention of employees was one of the greatest challenges affecting many organizations in both public and private sectors. The foregoing challenges are attributed to the effects of globalization, intensified competition, and also increased staff mobility particularly among the highly skilled employees. The study further established that the growth of public universities in Kenya which is manifested in the institutional success and sustainability hugely depend on the academic staff especially in the face of stiff competition in the higher education sector. Some of the identified factors that influence employee retention is the opportunities for personal growth particularly through promotion. Growth of academic staff through training and development is likely to impact positively on the organizational growth of universities in Kenya.

A study done in Kenya analyzed the role of competitive strategies on performance of private universities [15]. The study was a case of Mount Kenya University, which is hitherto one of the leading private universities in Kenya particularly in respect tin enrollment. The study population comprised the 240 staff working at the main campus of the Mount Kenya University based in Thika. The study observed that in the past twenty years, there has been unprecedented growth of demand for higher education at the university level. Yet against this backdrop, it is posited that for growth in institutions of higher education to be sustained, competitive strategies must be embraced.

\section{Research Methodology}

This research adopted a mixed research design. Both descriptive survey design and correlational design were adopted. It is stated that surveys are often employed together with correlational research design. Survey research design refers to the use of a survey which is administered either in writing or verbally, with the purpose of quantifying, describing, and/or characterizing an individual or group of individuals [16]. In the same vein, it is postulated that correlational design are employed when a study seeks to determine the relationship between variables (mainly predictor and dependent variables). For the purpose of

\section{Volume 6 Issue 7, July 2017 www.ijsr.net}




\section{International Journal of Science and Research (IJSR) \\ ISSN (Online): 2319-7064}

Index Copernicus Value (2015): 78.96 | Impact Factor (2015): 6.391

investigating the competitive strategies and their effects on performance of private universities the study focused on the management and marketing staff working with the private universities in Nairobi County.

A formula was employed to calculate the sample size [17]. After calculations, the sample was determined to be 72 respondents. The respondents were drawn from the study population using stratified random sampling in order to ensure fair and equitable distribution of respondents across marketing and management staff working with private universities in Nairobi County. For the purpose of collecting data on the effects of competitive strategies on the performance of private universities, primary data were collected using questionnaires. The questionnaires were preferred in this study because respondents of the study were literate and also able to answer questions asked adequately. The research instrument was first pilot tested in order to determine both its validity and reliability before it was employed for data collection in the main study.

Validity is the degree to which the instrument measures what it purports to measure [18]. To determine the content validity of the instrument in this study, the questionnaires was reviewed by the researcher with the help of the supervisor on the relevance of the content of the research questionnaire. Reliability, on the other hand, is a measure of the degree to which instrument yields consistent results after repeated trials. The Cronbach alpha coefficient was used to test the reliability and the pertinent results are shown in Table 1.

Table 1: Reliability Test Results

\begin{tabular}{|c|c|c|c|}
\hline Study construct & $\begin{array}{c}\text { No. of } \\
\text { items }\end{array}$ & $\begin{array}{c}\text { Cronbach } \\
\text { alpha }\end{array}$ & Comment \\
\hline Differentiation strategies & 5 & 0.80 & Reliable \\
\hline Organizational growth & 5 & 0.81 & Reliable \\
\hline
\end{tabular}

The researcher collected the data in person from the sampled respondents.

\subsection{Data Analysis and Presentation}

Data analysis is the whole process which starts immediately after data collection and ends when processed results are interpreted. The Statistical Package for Social Sciences (SPSS) version 24 tool was employed to facilitate in data processing and analysis. The collected data were analyzed by use of both descriptive and inferential statistics. Descriptive statistics took the form of measures of distribution, central tendencies, and variation while inferential statistics were in form of chi-square that was employed to test the null hypotheses. The results of the analyses were presented in form of tables.

\subsection{Results and Discussions}

The study first determined the response rate, which refers to the number of questionnaires that are correctly filled in comparison to the total number of questionnaires that were distributed to the respondents. In this respect, therefore, response rate is also referred to as questionnaire return rate. In this particular study, a total of 72 questionnaires were issued to the sampled respondents who constituted marketing and management staff working with private universities in Nairobi City County. From this number, the questionnaires that were filled rightly or according to instructions totalled 54. Therefore, the response rate was $75.0 \%$ which is the response rate threshold in survey studies [19].

\subsubsection{Differentiation Strategies}

The study further evaluated the views of marketing and management staff of private universities in Nairobi County on differentiation strategies. The pertinent descriptive statistics are as shown in Table 2.

Table 2: Descriptive Statistics for Differentiation Strategies

\begin{tabular}{|c|c|c|c|c|c|c|}
\hline & $\mathrm{n}$ & $\mathrm{SD}$ & $\mathrm{D}$ & $\mathrm{N}$ & $\mathrm{A}$ & $\mathrm{SA}$ \\
\hline $\begin{array}{c}\text { Private universities offer a } \\
\text { variety of academic programmes }\end{array}$ & 54 & 5.6 & 0 & 0 & 16.7 & 77.8 \\
\hline $\begin{array}{c}\text { Our university allows varied } \\
\text { modalities of paying tuition and } \\
\text { other fees }\end{array}$ & 54 & 0 & 0 & 0 & 50.0 & 50.0 \\
\hline $\begin{array}{c}\text { The academic modules offered } \\
\text { by our institution are flexible }\end{array}$ & 54 & 0 & 0 & 0 & 61.1 & 38.9 \\
\hline $\begin{array}{c}\text { Our university has different } \\
\text { academic modules }\end{array}$ & 54 & 0 & 0 & 0 & 72.2 & 27.8 \\
\hline $\begin{array}{c}\text { Some of the academic courses } \\
\text { offered by our university are } \\
\text { unique to it }\end{array}$ & 54 & 11.1 & 16.7 & 0 & 50.0 & 22.2 \\
\hline
\end{tabular}

The study observed that majority $(77.8 \%)$ of the marketing and management staff sampled strongly concurred that private universities offered a variety of academic programmes. These findings concurred with previous observations on competitive strategies that are employed by private universities in Kenya [5]. The study had observed that institutions of higher learning had differentiated the products that they offered. Subsequently, the foregoing enabled them to have a competitive edge over their rivals in the education sector. All the respondents either agreed $(50 \%)$ of strongly agreed $(50 \%)$ that these academic institutions allowed varied modalities of paying tuition and other fees. It was further revealed that respondents were in agreement that the academic modules offered by private universities were flexible $(\mathrm{A}=61.1 \%$; $\mathrm{SA}=38.9 \%)$, and that these institutions had different academic modules $(\mathrm{A}=$ $72.2 \% ; \mathrm{SA}=27.8 \%$ )

In addition, $50 \%$ and $22.2 \%$ of the respondents agreed and strongly agreed respectively with the proposition that some of the academic courses offered by universities were unique to them. However, this assertion drew varied reactions from the respondents with some strongly disputing $(\mathrm{SD}=11.1 \%$ ) while there were others that strongly admitted $(\mathrm{SA}=22.2 \%)$ that it was the case. The findings in the present study were in agreement with a previous study [20] where it was indicated that differentiation strategy was the second widely adopted strategy after focus strategy, in the context of chartered private universities in Kenya.

\section{Volume 6 Issue 7, July 2017 www.ijsr.net}




\section{International Journal of Science and Research (IJSR) ISSN (Online): 2319-7064}

Index Copernicus Value (2015): 78.96 | Impact Factor (2015): 6.391

\subsubsection{Organizational Growth}

The study further examined the views of management and marketing staff on growth of private universities. The pertinent findings are as shown in Table 3.

Table 3: Descriptive Statistics for Organizational Growth

\begin{tabular}{|c|c|c|c|c|c|c|}
\hline & $\mathrm{n}$ & $\mathrm{SD}$ & $\mathrm{D}$ & $\mathrm{N}$ & $\mathrm{A}$ & $\mathrm{SA}$ \\
\hline $\begin{array}{c}\text { Private universities have } \\
\text { recorded increased student } \\
\text { enrolment in the recent past }\end{array}$ & 54 & 0 & 0 & 0 & 27.8 & 72.2 \\
\hline $\begin{array}{c}\text { The number and variety of } \\
\text { courses offered by our } \\
\text { institution has increased over } \\
\text { the years }\end{array}$ & 54 & 0 & 0 & 0 & 33.7 & 66.7 \\
\hline $\begin{array}{c}\text { The physical infrastructure } \\
\text { including lecture rooms, } \\
\text { libraries and hostels among } \\
\text { others has been on an expansion } \\
\text { trail }\end{array}$ & 54 & 0 & 0 & 0 & 50 & 50 \\
\hline $\begin{array}{c}\text { The employees working with } \\
\text { private universities is on the rise }\end{array}$ & 54 & 0 & 0 & 0 & 66.7 & 33.3 \\
\hline $\begin{array}{c}\text { Private universities have opened } \\
\text { several new campuses in recent }\end{array}$ & 54 & 0 & 5.6 & 0 & 83.3 & 11.1 \\
\hline
\end{tabular}

According to the study findings shown in Table $3,72.8 \%$ of the sampled managers and marketers strongly agreed that private universities have recorded increased student enrolment in the recent past. This indicated a continuation of past trend in the context of Sub-Saharan Africa. According to the World Bank, the enrolment of students has increased more than three folds from 2.7 million in 1991 to 9.3 million in 2006. The World Bank report had further projected a rise of enrolment of university students to the region of 18 million to 20 million in 2015 across Africa. Therefore, the present study conducted in 2017 has furthered the argument in the World Bank's projection. In Kenya, a past study [5] concurred with the present study in reference to the growth in private universities as manifested by student enrolment. The scholars had noted that there had been conspicuous growth in private universities in Kenya which had enrolled $20 \%$ of the university entrants. Moreover, the study had acknowledged that the public universities were feeling threatened by the increased enrolment of students in private institutions of higher education to a point that they had to expand their institutions.

On the same note, the remaining respondents $(27.8 \%)$ agreed with the statement. All the respondents at least agreed that the number and variety of courses offered by these institutions have increased over the years $(\mathrm{A}=33.7 \%$; $\mathrm{SA}=$ $66.7 \%$ ). It was also revealed that $50 \%$ of the respondents agreed while a similar percentage strongly concurred that the physical infrastructure including lecture rooms, libraries and hostels among others has been on an expansion trail. Moreover, the study observed that respondents were in agreement $(\mathrm{A}=66.7 \%$; $\mathrm{SA}=33.3 \%)$ that number of employees working with private universities is on the rise. In addition, it was agreed and strongly concurred by $83.3 \%$ and $11.1 \%$ of the respondents that private universities have opened several new campuses in the recent past. Only 5.6\% of the sampled respondents held the view that the aforesaid institutions had not opened new campuses. Essentially, therefore, the findings generally indicated that private universities have recorded growth in various spheres including student enrolment, number and variety of courses offered, physical infrastructure, staff, and also number of satellite campuses. The foregoing findings supported observations made in a previous [5]. The findings from the latter study indicated that private universities in Kenya had experienced exponential growth in the recent past; though, the rapid growth of these academic institutions of higher learning had not been accompanied by enhanced of quality standards.

\subsubsection{Relationship between Differentiation Strategies and Organizational Growth}

The study adopted Spearman rank correlation to illustrate the relationship between differentiation strategies and growth of private universities in Nairobi County. Spearman's correlation is a non-parametric measure of the strength and direction between two variables measured on at least an ordinal scale. The results of the correlation analysis are presented in a correlation matrix reflected in Table 4.

Table 4: Spearman Rank Correlation Matrix

\begin{tabular}{|c|c|c|c|c|}
\hline & & & $\mathbf{1}$ & $\mathbf{2}$ \\
\hline \multirow{4}{*}{$\begin{array}{c}\text { Spearman's } \\
\text { rho }\end{array}$} & $\begin{array}{c}\text { Differentiation } \\
\text { strategies }\end{array}$ & $\begin{array}{c}\text { Correlation } \\
\text { Coefficient }\end{array}$ & 1.000 & \\
\cline { 3 - 5 } & & Sig. (2-tailed) &. & \\
\cline { 2 - 5 } & $\begin{array}{c}\text { Organizational } \\
\text { growth }\end{array}$ & $\begin{array}{c}\text { Correlation } \\
\text { Coefficient }\end{array}$ & $.780^{* *}$ & 1.000 \\
\cline { 3 - 5 } & & Sig. (2-tailed) & .000 &. \\
\cline { 3 - 5 } & & $\mathrm{n}$ & 54 & 54 \\
\hline
\end{tabular}

**. Correlation is significant at the 0.01 level (2-tailed).

As shown in Table 4, it was indicated that there existed positive, strong and significant relationship between differentiation strategies and organizational growth $\left(r_{\mathrm{s}}=\right.$ $0.780 ; p=<0.05)$. The results implied that the more private universities adopted differentiation strategies the more they were likely to record growth.

\subsubsection{Effect of Differentiation Strategies on}

\section{Organizational Growth}

The study examined the extent to which competitive strategies impacted on growth of private universities in Nairobi County. The results are presented in form of general correlation (R), coefficient of determination $\left(\mathrm{r}^{2}\right)$, analysis of variance (ANOVA), and regression coefficients. The results indicated in Table 5 outlines both $\mathrm{R}$ and $\mathrm{R}^{2}$.

Table 5: Model Summary

\begin{tabular}{|c|c|c|c|c|}
\hline Model & $\mathrm{R}$ & $\mathrm{R}$ Square & $\begin{array}{c}\text { Adjusted R } \\
\text { Square }\end{array}$ & $\begin{array}{c}\text { Std. Error of the } \\
\text { Estimate }\end{array}$ \\
\hline 1 & $.781^{\mathrm{a}}$ & .609 & .602 & .30151 \\
\hline \multicolumn{4}{|c|}{ a. Predictors: (Constant), Differentiation Strategies } \\
\hline
\end{tabular}

The study results indicated in Table 5 show that the relationship between differentiation strategies and growth of private universities was positive and strong $(\mathrm{R}=0.781)$. As further indicated in Table 6 , the foregoing relationship was found to be statistically significant $(F=81.068 ; p<0.05)$. The findings meant that the more differentiation strategies were adopted and implemented the greater the likelihood of private universities to record growth. The results of coefficient of determination $\left(\mathrm{R}^{2}=0.609\right)$ indicated that

\section{Volume 6 Issue 7, July 2017 www.ijsr.net}




\section{International Journal of Science and Research (IJSR) \\ ISSN (Online): 2319-7064}

Index Copernicus Value (2015): 78.96 | Impact Factor (2015): 6.391

$60.9 \%$ of growth of private universities could be attributed to differentiation strategies adopted by the institutions.

Table 6: Analysis of Variance

\begin{tabular}{|c|l|r|r|r|r|r|}
\hline \multicolumn{2}{|c|}{ Model } & $\begin{array}{r}\text { Sum of } \\
\text { Squares }\end{array}$ & df & $\begin{array}{r}\text { Mean } \\
\text { Square }\end{array}$ & F & Sig. \\
\hline 1 & Regression & 7.37 & 1 & 7.37 & 81.1 & $.000^{\mathrm{a}}$ \\
\cline { 2 - 7 } & Residual & 4.727 & 52 & 0.091 & & \\
\cline { 2 - 7 } & Total & 12.097 & 53 & & & \\
\hline \multicolumn{6}{|l|}{ a. Predictors: (Constant), Differentiation Strategies } \\
\hline
\end{tabular}

In addition, the study examined the extent to which differentiation strategies influenced growth of private universities. Table 7 shows the pertinent results.

Table 7: Regression Coefficients

\begin{tabular}{|c|c|c|c|c|c|r|}
\hline \multicolumn{2}{|c|}{} & $\begin{array}{c}\text { Unstandardized } \\
\text { Coefficients }\end{array}$ & $\begin{array}{l}\text { Standardized } \\
\text { Coefficients }\end{array}$ & & \\
\cline { 3 - 6 } \multicolumn{2}{|c|}{} & Model & $\begin{array}{c}\text { Std. } \\
\text { Error }\end{array}$ & Beta & t & Sig. \\
\hline 1 & (Constant) & 0.593 & 0.4 & & 1.49 & 0.14 \\
\cline { 2 - 6 } & $\begin{array}{c}\text { Differentiation } \\
\text { Strategies }\end{array}$ & 0.884 & 0.1 & 0.781 & 9 & 0 \\
\hline \multicolumn{3}{|c|}{ a. Dependent Variable: Organizational Growth } \\
\hline
\end{tabular}

The regression model adopted was as follows.

$\mathbf{Y}=\boldsymbol{\beta}_{0}+\beta_{1} \mathbf{X}_{1}+\varepsilon$

$Y=0.593+0.884 X_{1}$

Where $X_{1}$ represents differentiation strategies adopted by private universities while $\mathrm{Y}$ represented organizational growth. As shown above, every unit increase in the growth of private universities was as a result of 0.884 unit increase in differentiation strategies while holding other factors (0.593) constant.

\subsubsection{Testing Null Hypothesis $\left(\mathrm{H}_{0}\right)$}

The study employed the Chi-Square statistics to test the null hypothesis $\left(\mathrm{H}_{0}\right)$. The null hypothesis was tested at $95 \%$ confidence level which is equivalent to $5 \%$ margin of error or probability ( $p$-value) value of 0.05 .

$\mathbf{H}_{\mathbf{0}}$ : There is no significant relationship between differentiation strategies and growth of private universities in Nairobi County.

$\mathbf{H}_{\mathbf{A}}$ : There is significant relationship between differentiation strategies and growth of private universities in Nairobi County.

Table 8: Chi-Square Test Results

\begin{tabular}{|c|c|c|c|}
\hline & Value & df & Asymp. Sig. (2-sided) \\
\hline Pearson Chi-Square & $198.380^{\mathrm{a}}$ & 108 & .000 \\
\hline Likelihood Ratio & 135.496 & 108 & .038 \\
\hline Linear-by-Linear Association & 32.289 & 1 & .000 \\
\hline n of Valid Cases & 54 & & \\
\hline
\end{tabular}

a. 130 cells $(100.0 \%)$ have expected count less than 5 . The minimum expected count is .06 .

The chi-square test results shown in Table 8 revealed that the association between differentiation strategies and growth of private universities was statistically significant $\left(\chi^{2}=\right.$
$198.380 ; p<0.05)$. Therefore, the null hypothesis $\left(\mathrm{H}_{0}\right)$ was rejected.

\section{Summary, Recommendations \\ Conclusions}

and

This section outlines a summary of major findings, conclusions drawn and recommendations made. All these sections are in line with the study objectives.

\subsection{Summary}

The study observed that private universities offered a variety of academic programmes. The foregoing view reinforced observations made in a previous analytical study on the competitive strategies employed by private universities in Kenya [5]. The study had revealed that private universities had differentiated their products and services. The study also observed that these institutions allowed varied modalities of paying tuition and other fees. Moreover, it was established that the academic modules offered by private universities were flexible, and that these institutions had different academic modules. In addition, it was noted that some of the academic courses offered by universities were unique to them. The study also revealed that the more private universities adopted differentiation strategies the more they were likely to record growth.

The study revealedthat private universities have recorded increased student enrolment in the recent past. It was also observed that the number and variety of courses offered by these institutions have increased over the years. More so, the study noted that the physical infrastructure including lecture rooms, libraries and hostels among others has been on an expansion trail. Moreover, the study observed that the number of employees working with private universities is on the rise. The foregoing observation concurred with the revelation in astudy on determinants of academic employee retention in public universities in Kenya [14]. It was generally indicated that private universities have recorded growth in various spheres including student enrolment, number and variety of courses offered, physical infrastructure, staff, and also number of satellite campuses.

\subsection{Conclusions}

The study concluded that private universities in Nairobi County offered a variety of academic programmes, modules and courses. Moreover, it was inferred that the academic modules offered by private universities were flexible. The foregoing led to the inference that private universities in Nairobi City County had differentiated themselves in various ways compared to similar private universities and also institutions of higher education in the public sector. In addition, the study deduced that differentiation strategies were imperative in enhancing growth of private universities. The study concluded that private universities have recorded increased student enrolment in the recent past. The number and variety of courses offered by these institutions were inferred to have increased over the years. Also, the study deduced that there has been an expansion trail in respect to the physical infrastructure including lecture rooms, libraries and hostels among others. The student enrolment, workforce

Volume 6 Issue 7, July 2017 www.ijsr.net 


\section{International Journal of Science and Research (IJSR) \\ ISSN (Online): 2319-7064 \\ Index Copernicus Value (2015): 78.96 | Impact Factor (2015): 6.391}

and campuses were concluded to be on the rise among private universities in Nairobi County. It was concluded that cost leadership, differentiation and focus strategies were significantly important in regard to growth of private universities; however, differentiation strategies were the most important.

\subsection{Recommendations}

The study recommends that private universities should have programmes and offer academic courses that are in tandem with their core values and core functions and those that are within their means. In this sense, therefore, it is imperative for private universities to offer only those courses and programmes which it has the requisite capacity in order to avoid straining its resources.

The study also recommended that that the growth of private universities should also be balanced. This implies that as the student enrolment increases, so should be the faculty, subordinate staff, and infrastructure. Anything short of the foregoing is likely to precipitate many problems to these institutions in the long run. The expansion of universities in terms of courses being offered, academic modules and programmes, and satellite campuses should be in line with the guidelines of the CUE.

\section{References}

[1] Grant, R.M. (2002). Contemporary Strategy Analysis. ( $4^{\text {th }}$ Ed.). Oxford: Blackwell.

[2] Thompson A., \& Strickland, A.J. (2002). Strategic Management: Concepts and Cases. New York: Irwin.

[3] Johnson C., Scholes G., \& Whittington, M. (2006) Creativity in science and technology, values and creativity. Creativity Research Journal, 19, 105-122.

[4] Fisseha, M.G. (2010). Revenue Generation Strategies in Sub-Saharan African Universities. PhD thesis, University of Twente, Addis Ababa, Ethiopia.

[5] Kimando,L., Njogu, G.W., \&Sakwa, M. (2012). An analysis of the competitive strategies employed by private universities in Kenya: A case of private universities in Nairobi. Management Science and Engineering, 6(2), 55-70.

[6] Collins, D.W., Maydew, E., \& Weiss, I. (1997). Changes in the value relevance of earnings and book values over the past forty years. Journal of Accounting and Economics, 24, 39-67.

[7] Belsley, D., Kuh, E., \&Welseh, R. (1980). Regression diagnostics: Identifying Influential Data and CoLinearity. New York: Wiley

[8] Barney, J. B. (2002). Gaining and Sustaining Competitive Advantage. New Jersey: Prentice Hall.

[9] Hammer, M., \&Champy, J. (2010). Reengineering the Corporation, New York: Harper Business.

[10] Murage, D. (2011). The Competitive strategies in the petroleum industry. Unpublished MBA Project, Kenya Methodist University.

[11] Nderitu, J.W., Minja, D., \&Muriithi, S. (2014). An investigation of challenges facing Christian universities in Kenya: A case study of Pan Africa University, Nairobi, Kenya. International Journal of Management Science, 4(3), 129-143.
[12]Zhou, Y., Xu, G., Su, J., and Minshall, T. (2011). Barriers to entrepreneurial growth: An empirical study on university spin-offs in China. Journal of Science and Technology Policy in China, 2(3), 277 -294.

[13] Gudo, C.W., Oanda, I.O., \&Olel, M.A. (2011). Role of institutional managers in quality assurance: Reflections on Kenya's university education. Australian Journal of Business and Management Research, 1(2), 113 - 124.

[14] Ng'ethe, J.M., Iravo, M.E., \&Namusonge, G.S. (2012). Determinants of academic staff retention in public universities in Kenya: Empirical review. International Journal of Humanities and Social Science, 2(13), 205212.

[15] Kiptum, R.K., \&Ombui, K. (2015). The role of competitive strategies on performance of private universities in Kenya: A case of Mount Kenya University. International Journal of Education Research, 3(2), 21-38.

[16] Shaughnessy, J.J., Zechmeister, E.B., and Zechmeister, J.S. (2002). Research Methods in Psychology. New York: McGraw-Hill.

[17] Nassiuma, K. (2000). Survey sampling: Theory and methods. Nairobi, Kenya: Nairobi University Press.

[18] Kimberlin, C.L., andWinterstein, A.G. (2008). Research fundamentals. Am J Health SystPharm, 65.

[19] Nulty, D.D. (2008). The adequacy of response rates to online and paper surveys: What can we do? Assessment \& Evaluation in Higher Education, 33(3), 301-314.

[20] Gatembe, C. (2012). Relationship between Competitive Strategies and Performance of Chartered Private Universities in Kenya. MBA project, University of Nairobi, Nairobi, Kenya.

\section{Author Profile}

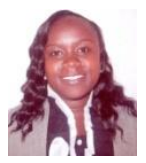

Nyambura Mary is an MBA (Marketing Option) degree finalist at Kenya Methodist University. She is also a holder of a Bachelor of Commerce (Marketing Option) degree from Nazarene University, Kenya.She currently works with the St Paul's University in Nairobi, Kenya as a Senior Administrative Assistant. 